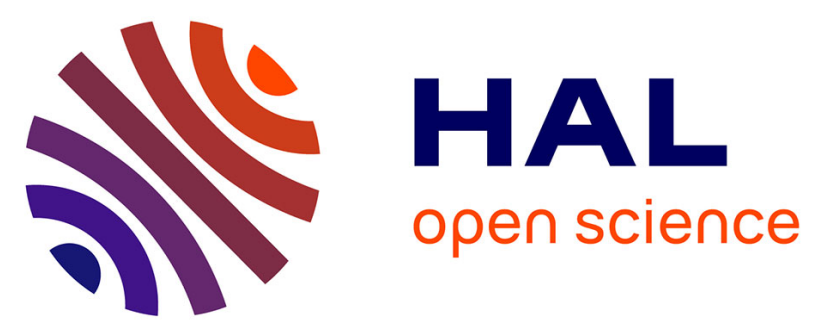

\title{
A new arginase enzymatic reactor: Development and application for the research of plant-derived inhibitors
}

\author{
C. André, G. Herlem, T. Gharbi, Y.-C. Guillaume
}

\section{To cite this version:}

C. André, G. Herlem, T. Gharbi, Y.-C. Guillaume. A new arginase enzymatic reactor: Development and application for the research of plant-derived inhibitors. Journal of Pharmaceutical and Biomedical Analysis, 2011, 55 (1), pp.48-53. 10.1016/j.jpba.2011.01.003 . hal-00605447

\section{HAL Id: hal-00605447 \\ https://hal.science/hal-00605447}

Submitted on 12 May 2021

HAL is a multi-disciplinary open access archive for the deposit and dissemination of scientific research documents, whether they are published or not. The documents may come from teaching and research institutions in France or abroad, or from public or private research centers.
L'archive ouverte pluridisciplinaire HAL, est destinée au dépôt et à la diffusion de documents scientifiques de niveau recherche, publiés ou non, émanant des établissements d'enseignement et de recherche français ou étrangers, des laboratoires publics ou privés. 


\title{
A new arginase enzymatic reactor: Development and application for the research of plant-derived inhibitors
}

\author{
Claire Andréa ${ }^{a, b}$, Guillaume Herlem ${ }^{\mathrm{a}, \mathrm{b}}$, Tijani Gharbi ${ }^{\mathrm{a}, \mathrm{b}}$, Yves Claude Guillaume ${ }^{\mathrm{a}, \mathrm{b}, \mathrm{c}, *}$ \\ a Univ-Franche Comte, F-25000, Besancon, France \\ ${ }^{\mathrm{b}}$ Nanomedecine Lab, Imagery, Therapeutic (EA4267), Laboratoire de Chimie Analytique et Physique, F-25000, Besancon, France \\ c CHU Besancon, Pôle Pharmaceutique, F-25000, Besancon, France
}

\begin{abstract}
This work was dedicated to the development of a new micro immobilized enzyme reactor (IMER) by using an in situ procedure. Arginase was covalently immobilized on an ethylenediamine (EDA) monolithic convective interaction media (CIM) disk (12 mm $\times 3 \mathrm{~mm}$ i.d.) previously derivatized with glutaraldehyde. The activity of this IMER was investigated by inserting this micro-IMER in a HPLC system. The effect of the arginase inhibitors was evaluated by the simultaneous injection of each inhibitor with the nitro guanidino benzene (NGB) substrate. The relative IC50 values were found in agreement with those derived by the conventional spectrometric method. This arginase micro-IMER system was also used to study the effects of plantderived products on the arginase activity. The pet ether extract from the stem bark of the plant Ficus glomerata Roxob. and the procyanidin oligomers of cocoa and chocolate inhibit the arginase activity. Our results confirmed the direct effect of some plant extracts on the arginase activity and their interest in therapies for treating several NO-dependent smooth disorders.
\end{abstract}

\section{Introduction}

Immobilization procedures have been found appropriate to covalently bind enzymes to modified silica matrices, with retention of enzymatic activity [1-4]. Monoliths are considered an interesting generation of stationary phases. The large pores of monolithic materials allow high-speed analysis and low back pressure. In particular monolithic disks based on a new polymeric macroporous material and available under the trademark convective interaction media (CIM) were chosen because promising for analytical application due to reduced time analysis and high enzyme efficiency [5]. Arginase catalyzes the hydrolysis of arginine-ornithine and urea. In mammals, there are two isoforms of arginase. Arginase I is the cytosolic form that participates in the urea cycle and is expressed at high level in the liver [6]. By contrast, arginase II is localized in the mitochondria and is highly expressed in the kidney [6]. Recently, the demonstration that both arginase isoforms are expressed by vascular endothelial and smooth muscle cells rise interest to this enzyme in cardiovascular physiology and pathology [7]. Of interest, arginase was found to reciprocally regulate nitric oxide (NO) levels in endothelial cells by competing

\footnotetext{
* Corresponding author at: Lab. de chimie, Place Saint-Jacques, F-25030, Besancon, France. Tel.: +33 3816655 44; fax: +33 381665655 .

E-mail address: yves.guillaume@univ-fcomte.fr (Y.C. Guillaume).
}

with NO synthase for the substrate L-arginine [8]. Recently our group demonstrated that arginase inhibition improves endothelial function and lowers blood pressure on spontaneously hypertensive rats $[9,10]$ and the binding of arginase inhibitors with the enzyme using a novel biochromatographic column [11,12] was studied. In the present study arginase was for the first time covalently immobilized on an amine monolithic activated support obtained by reacting the native epoxy groups with a convenient ethylene diamine spacer. Originally developed as weak ion exchange column, EDA monolithic disk can be used for bioconversion by coupling proteins, peptides or other ligands through cross linking reaction with a suitable bifunctional reagent i.e., glutaraldehyde. The arginase-immobilized enzyme reactor (IMER) was placed in a liquid chromatographic system and on-line chromatographic studies were performed. Kinetics characteristics of this IMER were determined using a chromogenic substrate; the 1-nitro3-guanidinobenzene (NGB). The effects of enzymatic activity of different parameters such as mobile phase $\mathrm{pH}$, flow rate were carefully studied. This new IMER presented advantages over the previously performed immobilization of arginase [11] in terms of very short analysis time, absence of back pressure, lower specific matrix interactions and immediate recovery of enzyme activity. The immobilized enzyme can be placed in an on-line system for rapid screening of compounds for inhibitory activity. As well, the direct effect of some plant-derived products on the arginase activity was analysed. 


\section{Materials}

\subsection{Reagents}

EDA-CIM disk $(12 \mathrm{~mm} \times 3 \mathrm{~mm}$ ) were purchased from Interchim (Montluçon, France). Arginase was purchased from Sigma (Paris, France), glutaraldehyde, and sodium cyanoborohydride from Interchim (Montluçon, France). Monoethanolamine was obtained from Sigma (Paris, France). NOHA, nor-NOHA, BEC, ABH, were obtained from Bachem (Germany). Water was obtained from an Elgastat option water purification system (Odil, Talant, France) fitted with a reverse osmosis cartridge. All the other chemical products were of analytical grade and all the buffer solutions were filtered through a $0.45 \mu \mathrm{m}$ membrane filter and degassed before their use for HPLC.

\subsection{Apparatus}

The high performance liquid chromatography (HPLC) system consisted of a Hewlett-Packard quaternary pump (1050), an Agilent (G1365B, Serie 1100) UV-Visible detector (Paris, France) and a Rheodyne 7725i injection valve (Cotati, CA, USA) fitted with a $20 \mu \mathrm{L}$ sample loop. An Interchim TM701 oven for high temperature was used.

\section{Methods}

\subsection{Arginase immobilization}

The in situ immobilization technique was considered in this study [1-4]. The immobilization of arginase via the amino groups of the enzyme and the CIM disk was carried out as follows. The EDA CIM disk was connected to an HPLC system and conditioned for $40 \mathrm{~min}$ with a mobile phase consisting of phosphate buffer $(50 \mathrm{mM}$, $\mathrm{pH}=7.00$ ) at $0.4 \mathrm{~mL} / \mathrm{min}$. Then the CIM disk was removed placed in a glass beaker, covered with $6 \mathrm{~mL}$ of a $13 \%$ glutaraldehyde solution in phosphate buffer $(50 \mathrm{mM}, \mathrm{pH}=6.00)$ and kept under stirring for $8 \mathrm{~h}$, in the dark. The reacted matrix was then washed with phosphate buffer ( $50 \mathrm{mM}$, pH 6.0). An aliquot of $800 \mu \mathrm{L}$ of arginase solution in phosphate buffer $(50 \mathrm{mM}, \mathrm{pH}=8.5)$ was added to the matrix and left to react overnight under gentle stirring. After immobilization, the UV absorbance decrease of the enzyme solution was determined to calculate the unreacted enzyme units. Schiff bases were reduced by stirring the arginase-CIM disk in a $10 \mathrm{~mL}$ solution of cyanoborohydride $(0.1 \mathrm{M})$ in phosphate buffer $(50 \mathrm{mM}, \mathrm{pH}=6.00)$ for $5 \mathrm{~h}$ at $25^{\circ} \mathrm{C}$

The matrix was then washed with phosphate buffer $(50 \mathrm{mM}$, $\mathrm{pH}=6.0$ ) to remove the unreacted reagent and stirred for $5 \mathrm{~h}$ with monoethanolamine $(0.2 \mathrm{M})$ in phosphate buffer $(50 \mathrm{mM}, \mathrm{pH}=8.50)$ at room temperature. The arginase-IMER was then inserted in the appropriate holder, connected to the HPLC system and washed with phosphate buffer $(50 \mathrm{mM}, \mathrm{pH}=7.4)$ for $1 \mathrm{~h}$ at a flow-rate of $0.4 \mathrm{~mL} / \mathrm{min}$. When not in use, the arginase-IMER was stored at $4{ }^{\circ} \mathrm{C}$ in phosphate buffer $(50 \mathrm{mM}, \mathrm{pH}=7.4)$ containing $0.1 \%$ sodium azide.

\subsection{Determination of immobilized arginase-IMER activity}

The activity of immobilized enzyme was determined in terms of active units $(\mathrm{U})$ using the chromophore m-nitro-aniline ( $\mathrm{m}$ NA) from the reaction between the enzyme with the substrate 1-nitro-3-guanidinobenzene (NGB) yielding products urea plus $\mathrm{m}$ NA [13]. The 1-nitro-3-guanidinobenzene (NGB) was synthesized as described in a previous paper [13]. One unit of enzymatic activity is defined as the amount of enzyme catalyzing the production of $1 \mu \mathrm{mol}$ of $\mathrm{m}-\mathrm{NA} / \mathrm{min}$, i.e., the number of micromoles of $\mathrm{m}-\mathrm{NA}$ produced by the enzymatic reaction of NGB. The arginase-IMER was

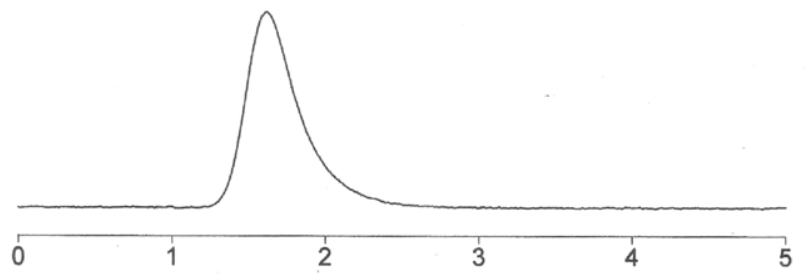

Fig. 1. Chromatogram obtained after the injection of $10 \mu \mathrm{L}$ of $190 \mathrm{mM}$ NGB. Mobile phase: $0.1 \mathrm{mM}$ Tris- $\mathrm{HCl}$ buffer $\mathrm{pH}=8.5,10 \mathrm{mM} \mathrm{MnCl}_{2}$. Flow rate: $0.4 \mathrm{~mL} / \mathrm{min}$. IMER temperature $=25^{\circ} \mathrm{C}$. Detection wavelength: $372 \mathrm{~nm}$ (corresponding to the peak of $\mathrm{m}-\mathrm{NA})$.

conditioned with the mobile phase i.e., $(0.1 \mathrm{mM}$ Tris- $\mathrm{HCl})$ buffer $\mathrm{pH}=8.5-10 \mathrm{mM} \mathrm{MnCl}_{2}$. Flow-rate was set at $0.4 \mathrm{~mL} / \mathrm{min}$ and $\mathrm{UV}$ detection at $372 \mathrm{~nm}$ corresponding to the maximal adsorption of $\mathrm{m}-\mathrm{NA}$ (at this wavelength, the adsorption of NGB is much less than of m-NA [13]). Aliquots of 20 (L of NGB were injected at increasing concentration (range comprised between 3 and $300 \mathrm{mM}$ ) and the Michaelis-Menten trend was found by plotting the rate of enzymatic reaction (V) against the substrate concentration [S]. An example of chromatogram is given in Fig. 1. The rate of the enzymatic reaction was expressed as $\Delta$ (area $\mathrm{m}-\mathrm{NA} / \mathrm{min}$ ) given by the expression area (m-NA)/(time (min)). The values are the means of two independent measurements. Time indicates the reaction time defined by the time for complete elution of the product in the IMER, which is dependent upon flow-rate. Kinetic parameters $V_{\max }$ and $K_{\mathrm{m}}$ were obtained thanks to the linear and Burk plot, which is a linear transformation of the Michaelis-Menten plot. The immobilized active units ( $\mathrm{U} \mu \mathrm{mol} / \mathrm{min}$ ) were determined by the expression $\Delta$ (area $\mathrm{m}-\mathrm{NA} / \mathrm{min}) \mathrm{max} / \varepsilon(\mathrm{m}-\mathrm{NA})$.IMER void volume $(\mathrm{mL})$. For the study of the flow-rate (see Section 3.4) $\varepsilon$ (m-NA) was defined for each flow-rate value. A correlation between adsorbance values and relative chromatographic peaks was obtained. For some experiments it was necessary to measure arginase activity in solution. The description was given in [13]. Briefly, to measure the arginase activity in solution (activity of the free enzyme), the concentrations of arginase stock solutions were determined from the absorbance at $280 \mathrm{~nm}$ and a stock solution of $200 \mathrm{mM}$ NGB in DMSO was prepared. Assays were performed in Tris- $\mathrm{HCl}$ buffer $-10 \mathrm{mM} \mathrm{MnCl} 2$ using a spectrophotometer detector with a detection wavelength equal to $372 \mathrm{~nm}$ corresponding to the liberated product m-NA.

\subsection{Binding site preparation for docking}

A molecular docking study of NGB with arginase receptor was performed using the Autodock [14] suite of programs including the AutoDockTools (ADT) interface [15]. The arginase-nor-NOHA complex (PDB entry code 1T4R) was used [16] for the docking assessment because the inhibitor co-crystallized with the substrate in its catalytic cavity. Polar hydrogens were added, all the water molecules were removed, Gasteiger charges were computed and the non-polar hydrogens were merged since this is expected by AutoDock for the input protein as well as for the ligands. Precalculation of atomic affinities using a grid box of $70 \times 70 \times 70$ points and $0.375 \AA \AA$ spacing at the grid centre (-6.157 45.4911 .87$)$, were performed with AutoGrid. Docking of each ligand was calculated with a conformation search via the Lamarckian Genetic 
Algorithm, a population size of 300, 200 runs and 25,000,000 maximum number of energy evaluations. All the other parameters were left at their default values. Analyses of the results were performed with ADT and Chimera [17].

\subsection{Optimization of the chromatographic conditions}

\subsubsection{Flow-rate}

Flow-rate determines the contact time between enzyme and substrate. A fixed saturating aqueous solution (190 mM) of NGB was injected five times on to the chromatographic system with a flow-rate comprised between 0.4 and $1.4 \mathrm{ml} / \mathrm{min}$ with UV detection at $372 \mathrm{~nm}$. The mobile phase was a $0.1 \mathrm{mM}$ Tris- $\mathrm{HCl}$ buffer $\mathrm{pH}=7.4-10 \mathrm{mM} \mathrm{MnCl}_{2}$ and $T=25^{\circ} \mathrm{C}$. The product area was integrated and the Michaelis-Menten plots were obtained and $K_{\mathrm{m}}$ and $V_{\max }$ were derived at each flow rate.

\subsubsection{Mobile phase $p H$}

The IMER was equilibrated for $30 \mathrm{~min}$ with $(0.1 \mathrm{mM}$ Tris- $\mathrm{HCl})$ buffer, $10 \mathrm{mM} \mathrm{MnCl}_{2}$ in a $\mathrm{pH}$ range comprised between 6.0 and 8.5 , $T=25^{\circ} \mathrm{C}$. A fixed saturating aqueous solution $(190 \mathrm{mM})$ of NGB was injected five times on to the chromatographic system with a flowrate of $0.4 \mathrm{~mL} / \mathrm{min}$ with UV detection at $372 \mathrm{~nm}$. The product peak area was integrated and plotted against the $\mathrm{pH}$ value of the mobile phase.

\subsubsection{Arg-IMER stability}

The IMER stability was determined by using $0.1 \mathrm{mM}$ Tris- $\mathrm{HCl}$ buffer $\mathrm{pH}=8.5,10 \mathrm{mM} \mathrm{MgCl}$ as mobile phase and injecting five times every day saturating aqueous solution $(190 \mathrm{mM})$ of NGB at a flow rate equal to $0.4 \mathrm{~mL} / \mathrm{min}$ and a detection wavelength equal to $372 \mathrm{~nm}$.

\subsection{Determination of inhibitory potency (IC50)}

Stock solutions of the test compounds (1-10 mM) were prepared in water or methanol. The assay solutions were prepared by diluting the stock solutions in water together with the substrate NGB at a fixed concentration (190 mM). In particular five different concentrations of each compound were mixed together with the substrate in order to obtain inhibition of arginase activity comprised between 20 and $80 \%$. Aliquot of $10 \mu \mathrm{L}$ of a solution containing $190 \mathrm{mM}$ NGB were injected into the chromatograph in triplicate and the area of peaks were determined $\left(A_{0}\right)$. The assay solutions containing increasing inhibitor concentration and a fixed substrate concentration were then injected into the chromatographic system and the relative peak areas were integrated $\left(A_{\mathrm{i}}\right)$.

The peak areas were compared with those obtained in absence and presence of inhibitor and \% of inhibition was calculated. The percent inhibition (PI) of the enzyme activity due to the presence of increasing test compound concentration was calculated by the following expression: $100-\left(A_{\mathrm{i}} / A_{0} \times 100\right)$ where $A_{\mathrm{i}}$ is the peak area calculated in the presence of inhibitor and $A_{0}$ is the peak area obtained with the substrate solution only. Inhibition curves were obtained for each compound by plotting the PI value versus the logarithm of inhibitor concentration in the assay solution. The linear regression parameters were determined for each curve and the IC50 extrapolated.

\subsection{Effect of an extract from Ficus glomerata Roxob. on the arginase activity}

The stem bark of the plant $F$. glomerata Roxob. was sun dried powdered and was extracted with petroleum ether at $70^{\circ} \mathrm{C}$. The extract was dried under vacuum and suspended in a $0.1 \mathrm{M} \mathrm{Tris-} \mathrm{HCl}$ buffer $\mathrm{pH}=8.5$ containing NGB at a concentration of $190 \mathrm{mM}$ so
Table 1

Results of the docking of nor-NOHA and NGB in the receptor of arginase concerning the score $\left(\Delta_{\mathrm{r}} G\right)$ and the resulting inhibition constant $K_{\mathrm{i}}$.

\begin{tabular}{lll}
\hline Ligand & $\Delta_{\mathrm{r}} G(\mathrm{kcal} / \mathrm{mol})$ & $K_{\mathrm{i}}(\mathrm{nmol})$ \\
\hline Nor-NOHA & -8.30 & 827.82 \\
NGB & -10.01 & 46.14 \\
\hline
\end{tabular}

as to obtain seven solution with a final volume of $2.5 \mathrm{~mL}$ containing $0.1 \%, 0.3 \%, 0.5 \%, 0.7 \%$ and $0.9 \%$ of the extract and a fixed NGB concentration. The percent inhibition (PI) of the enzyme activity due to the presence of increasing pet ether extract of stem bark was determined as explained above by injection five times 10 (L of each solution. The mobile phase was a $0.1 \mathrm{mM}$ Tris- $\mathrm{HCl}$ buffer $\mathrm{pH}=7.4,10 \mathrm{mM} \mathrm{MnCl}_{2}$ with a flow rate of $0.4 \mathrm{~mL} / \mathrm{min}, T=25^{\circ} \mathrm{C}$ and a detection wavelength equal to $372 \mathrm{~nm}$.

\subsection{Effect of procyanidins on the arginase activity}

The crude procyanidin (CP) and procyanidin enriched (PE) extracts (Mars Incorporated, Hackettstown, USA) were suspended in a $0.1 \mathrm{mM}$ Tris- $\mathrm{HCl}$ buffer $\mathrm{pH}=8.5$ containing NGB at a concentration of $190 \mathrm{mM}$ so as to obtain seven solution with a final volume of $2.5 \mathrm{~mL}$ containing $0.1 \%, 0.3 \%, 0.5 \%, 0.7 \%$ and $0.9 \%$ of the $\mathrm{CP}$ or PE powder and a fixed NGB concentration. The percent inhibition (PI) of the enzyme activity due to the presence of increasing $\mathrm{CP}$ or PE extracts was determined as explained above by injection five times of $10 \mu \mathrm{L}$ of each solution. The mobile phase was a $0.1 \mathrm{mM}$ Tris- $\mathrm{HCl}$ buffer $\mathrm{pH}=7.4,10 \mathrm{mM} \mathrm{MnCl}_{2}$ with a flow rate of $0.4 \mathrm{~mL} / \mathrm{min}, T=25^{\circ} \mathrm{C}$ and a detection wavelength equal to $372 \mathrm{~nm}$.

\section{Results and discussion}

\subsection{Molecular docking assay}

Comparative docking calculations of NGB and nor-NOHA in the binding site of arginase are gathered in Table 1. The scores indicated that the best docking binding energy was found for NGB compared to nor-NOHA and an inhibition constant for NGB smaller than for nor-NOHA. This result was expected since the strong mimetic structure of NGB (guanidine function) towards arginine, despite the hydrogen bonding network stabilizing the nor-NOHA-arginase complex [16]. The best docking conformation of NGB into the crystallographic receptor of arginase is shown in Fig. 2. The distance between the two $\mathrm{Mn}^{2+}$ ions is $3.4 \AA$. One $\mathrm{Mn}_{\mathrm{A}}^{2+}$ ion is chelated by His 101 and Asp 128. The other $\mathrm{Mn}_{\mathrm{B}}^{2+}$ ion is coordinated to Asp

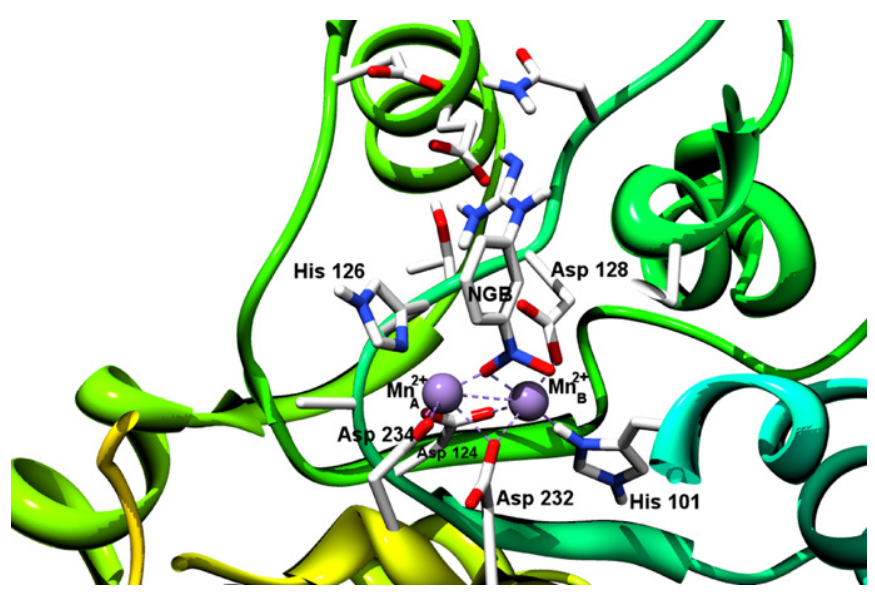

Fig. 2. Best docking conformation of NGB into the crystallographic receptor of arginase with the residues chelating the two $\mathrm{Mn}^{2+}$ ions. 


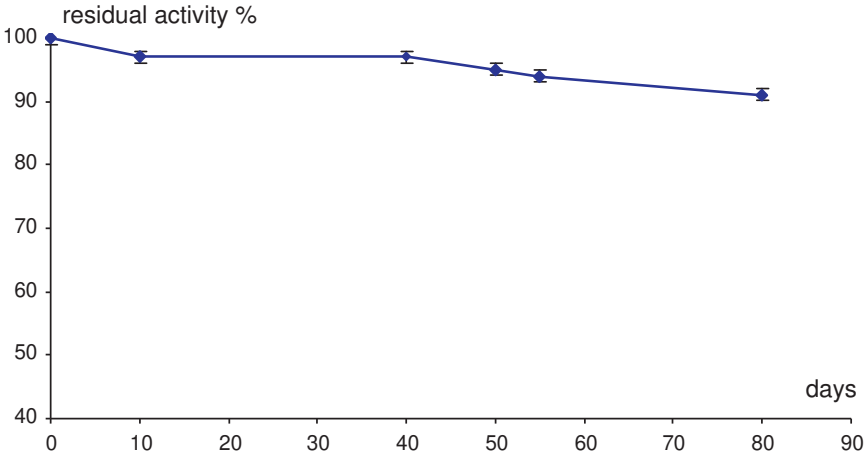

Fig. 3. Residual activity calculated as \% initial activity (m-NA peak) after $190 \mathrm{mM}$ NGB injection over time. Mobile phase: $0.1 \mathrm{mM}$ Tris- $\mathrm{HCl}$ buffer $\mathrm{pH}=8.5,10 \mathrm{mM}$ $\mathrm{MnCl}_{2}$. Flow rate: $0.4 \mathrm{~mL} / \mathrm{min}$. IMER temperature $=25^{\circ} \mathrm{C}$. Detection wavelength: $372 \mathrm{~nm}$.

124, Asp 232, Asp 234 and His126.The monodentate interaction between the NGB and the two $\mathrm{Mn}^{2+}$ ions induce one oxygen atom of the carboxylate group to be available.

\subsection{IMER stability and $\mathrm{pH}$ and flow-rate effects}

The immobilization yield of the enzyme on the CIM disk (IY) was found to be $9.6 \%$ by determining the activity of the enzyme solution before and after immobilization (see experimental conditions in Section 3.1).

The stability of the IMER was also examined. The optimal conditions of storage were investigated and phosphate buffer $50 \mathrm{mM}$, $\mathrm{pH}=7.4$ containing $0.1 \%(\mathrm{w} / \mathrm{v})$ sodium azide, resulted the most convenient. Buffers were freshly prepared every day. Under these storage conditions, after an initial lost of $8 \%$ of the enzyme activity, Arg-CIM disk enzymatic activity remained almost unchanged for over 80 days (Fig. 3 ). The influence of the mobile phase $\mathrm{pH}$ was evaluated and data obtained are shown in Fig. 4. As expected, the $\mathrm{pH}$ influenced enzyme activity. To define the influence of the $\mathrm{pH}$ on the IMER, a comparison between data obtained with the enzyme in the free and immobilized formats showed that immobilization did not alter the enzyme behaviour: enzyme activity increased with increasing $\mathrm{pH}$ values up to an optimal value around 8.5. The $K_{\mathrm{m}}$ value obtained in a $0.1 \mathrm{mM}$ Tris- $\mathrm{HCl}$ buffer, $10 \mathrm{mM} \mathrm{MgCl} 2$ was at $\mathrm{pH}=7.4,14.0 \pm 0.2 \mathrm{mM}$ and at $\mathrm{pH}=8.5,2.9 \pm 0.3 \mathrm{mM}$. This variation agrees with previous study which demonstrated that the $K_{\mathrm{m}}$ value decreased with the $\mathrm{pH}$ value. For human liver arginase enzyme, the $K_{\mathrm{m}}$ for arginine declined from 15.4 to $1.6 \mathrm{mM}$ over the $\mathrm{pH}$ range 6.5-9.5 [18]. As well, the $K_{\mathrm{m}}$ value should be treated with caution, because of the significant buffer effect. The $K_{\mathrm{m}}$ value for arginase catalyzed NGB hydrolysis in a $50 \mathrm{mM}$ Bicine- $\mathrm{NaOH}(\mathrm{pH}$ 8.5 ) was thus determined $1.8 \pm 0.4 \mathrm{mM}$. This value is nearly iden-

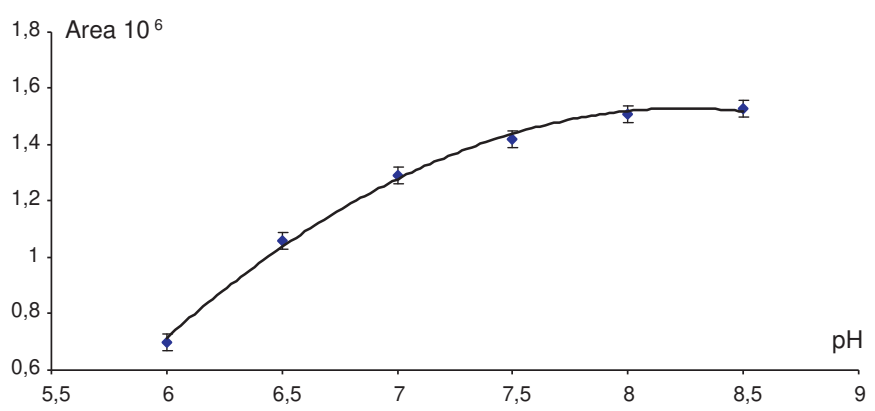

Fig. 4. Effect of $\mathrm{pH}$ on m-NA peak area after $190 \mathrm{mM}$ NGB injection. Mobile phase: $0.1 \mathrm{mM}$ Tris- $\mathrm{HCl}$ buffer, $10 \mathrm{mM} \mathrm{MnCl}_{2}$. Flow rate: $0.4 \mathrm{~mL} / \mathrm{min}$. IMER temperature: $25^{\circ} \mathrm{C}$. Detection wavelength: $372 \mathrm{~nm}$.
Table 2

Effect of the mobile phase flow-rate $F(\mathrm{~mL} / \mathrm{min})$ on $K_{\mathrm{m}}(\mathrm{mM})$ and $V_{\max }(\mu \mathrm{mol} / \mathrm{min})$ for arginase catalyzed NGB hydrolysis after $190 \mathrm{mM}$ NGB injection. Mobile phase: $0.1 \mathrm{mM}$ Tris- $\mathrm{HCl}$ buffer $\mathrm{pH}=7.4,10 \mathrm{mM} \mathrm{MnCl}_{2}$. IMER temperature: $25^{\circ} \mathrm{C}$. Detection wavelength: $372 \mathrm{~nm}$.

\begin{tabular}{lll}
\hline$F(\mathrm{~mL} / \mathrm{min})$ & $K_{\mathrm{m}}(\mathrm{mM})$ & $V_{\max }(\mu \mathrm{mol} / \mathrm{min})$ \\
\hline 0.4 & $14.3(0.2)$ & $142.0(0.1)$ \\
0.6 & $14.8(0.1)$ & $140.1(0.2)$ \\
0.8 & $14.6(0.3)$ & $137.3(0.3)$ \\
1.0 & $14.4(0.2)$ & $134.2(0.3)$ \\
1.2 & $14.1(0.1)$ & $132.4(0.2)$ \\
1.4 & $14.3(0.2)$ & $129.2(0.3)$ \\
\hline
\end{tabular}

Standard deviations were in parantheses.

tical to that obtained in a previous article [13] but lower than in tris. To investigate the flow rate effect on the arginase activity, the kinetic parameters $\left(V_{\max }\right.$ and $K_{\mathrm{m}}$ ) of arginase bioreactor were determined at different flow rates for a $0.1 \mathrm{mM}$ Tris-HCl buffer $\mathrm{pH}=7.4,10 \mathrm{mM} \mathrm{MnCl}_{2}$. As shown in Table 2 the effect of flow rate on the $K_{\mathrm{m}}$ value is very small while maximum velocies $V_{\max }$ slightly decreased. It might speculated that the increasing friction due to higher flow rate could negatively influence the enzyme catalytic efficiency by reversibly modifying the three dimensional structure of the immobilized enzyme.

\subsection{Determination of inhibitory potency (IC50)}

The sensitivity of the immobilized arginase in the column to the arginase inhibitors was examined. Four inhibitors were examined. Their IC50 were determined by the conventional method described briefly above. Then the IC50 of the four known inhibitors (NOHA, nor-NOHA, BEC, ABH) was assessed by using the immobilized enzyme column, by extrapolation from the inhibition curves. The inhibition curves were obtained by injecting simultaneously both the substrate at a fixed saturating concentration, as determined by the Michaelis-Menten plot, and inhibitors at increasing concentration. Increasing reduction of the m-NA peak area when compared to the area obtained by the sole substrate, was observed for increasing inhibitor concentration. The percent inhibition was plotted against the logarithm of inhibitor concentration to obtain the inhibition curves. The pIC50 (=-logIC50) values obtained on the arginase column were compared with the values obtained for the free enzyme and a valid correlation was obtained $\left(r^{2}=0.999\right)$. This will allow a direct comparison between on line determined inhibition potencies and PIC50 values determined with the classical spectrophotometric method. For example, the IC50 obtained with the IMER and the free enzyme were respectively equal to $10.3 \mu \mathrm{mol} / \mathrm{L}$, $10.8 \mu \mathrm{mol} / \mathrm{L}$ for NOHA, $0.58 \mu \mathrm{mol} / \mathrm{L}, 0.60 \mu \mathrm{mol} / \mathrm{L}$ for nor-NOHA and $0.54 \mu \mathrm{mol} / \mathrm{L}, 0.58 \mu \mathrm{mol} / \mathrm{L}$ for BEC. The values obtained were similar as those obtained for the biological substrate arginine [19]. These results indicated that the IMER could be used to on line screen for new inhibitors and the enzyme immobilization on the chromatographic support did not alter its biological properties. To evaluate the IMER to IMER reproducibility, three IMERs were prepared under identical conditions. The mobile phase was $0.1 \mathrm{mM}$ Tris- $\mathrm{HCl}$ buffer $\mathrm{pH}=7.4,10 \mathrm{mM} \mathrm{MnCl}_{2}$, the IMER was maintained equal to $25^{\circ} \mathrm{C}$ at a flow-rate of $0.4 \mathrm{~mL} / \mathrm{min}$. The $K_{\mathrm{m}}$ and $V_{\max }$ values for NGB and the immobilization yield (IY) for each IMER were calculated using these three IMERs (Table 3). The results showed that the technique was reliable and reproducible.

\subsection{Influence of plant-derived products on the arginase activity}

Fig. 5 reports all the data acquired on the evolution of the arginase activity when the pet ether extract from stem bark increased. This indicates that the pet ether extract from the stem 
Table 3

Evaluation of $K_{\mathrm{m}}, V_{\max }$ and IY for IMER to IMER, reproducibility (i.e., arginase column). Mobile phase: $0.1 \mathrm{mM}$ Tris- $\mathrm{HCl}$ buffer $\mathrm{pH}=7.4,10 \mathrm{mM} \mathrm{MnCl}_{2}$. Flow-rate: $0.4 \mathrm{~mL} / \mathrm{min}$. Detection wavelength: $372 \mathrm{~nm}$. IMER temperature: $25^{\circ} \mathrm{C}$.

\begin{tabular}{llll}
\hline IMER & $K_{\mathrm{m}}(\mathrm{mM})$ & $V_{\max }(\mu \mathrm{mol} / \mathrm{min})$ & IY $(\%)$ \\
\hline 1 & $13.9(0.1)$ & $141.0(0.4)$ & $9.5(0.2)$ \\
2 & $14.0(0.1)$ & $139.1(0.5)$ & $9.6(0.1)$ \\
3 & $14.1(0.2)$ & $139.1(0.3)$ & $9.6(0.1)$ \\
\hline
\end{tabular}

Standard deviations were in parantheses.

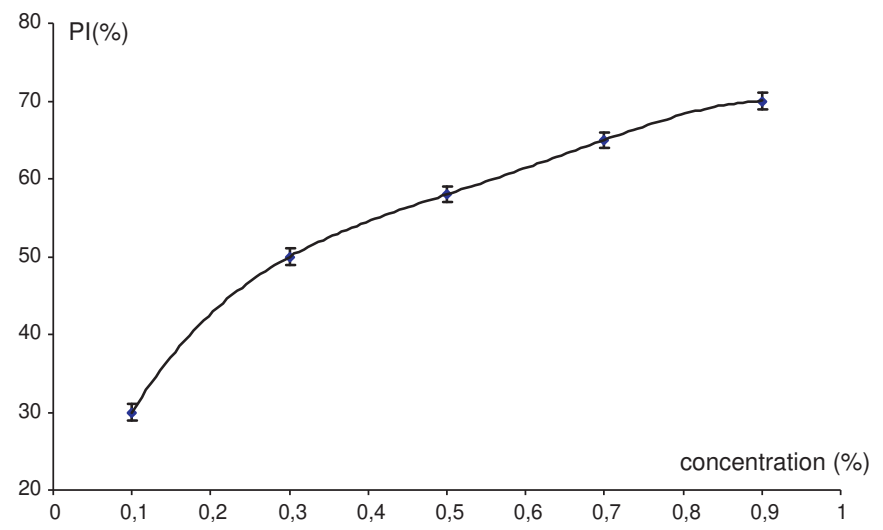

Fig. 5. Direct effect of Pet ether extract of stem bark from Ficus glomerata Roxob. on arginase activity. Mobile phase: $0.1 \mathrm{mM}$ Tris- $\mathrm{HCl}$ buffer $\mathrm{pH}=7.4,10 \mathrm{mM} \mathrm{MnCl}$. Flow rate: $0.4 \mathrm{~mL} / \mathrm{min}$. IMER temperature: $25^{\circ} \mathrm{C}$. Detection wavelength: $372 \mathrm{~nm}$. PI: percent inhibition.

bark of the plant deactivated the enzyme. This result was in accordance with the work of Raman et al. [20]. As well, Fig. 6 showed that the $\mathrm{CP}$ and $\mathrm{PE}$ extracts caused a significant decrease in the arginase activity, this effect being enhanced with the PE extract. This finding demonstrated clearly and for the first time the direct effect of procyanidins on the arginase activity. In this article we analysed how the kinetics data responded to a change of the PE concentration of PE extract. The results obtained in Table 4 indicated that the $K_{\mathrm{m}}$ values did not change significantly. This was because there was no change on the binding site of the enzyme structure, so the enzyme affinity towards the substrate did not change either. Whereas the $V_{\max }$ values with the PE extract concentration were decreased. These results indicated classical deactivation kinetic without a significant influence on the rate of substrate binding [21]. PE extracts contained a high concentration of procyanidin polymers. For example, the quantity of decamer was $24.6 \mathrm{mg} / \mathrm{g}$ (value given by the

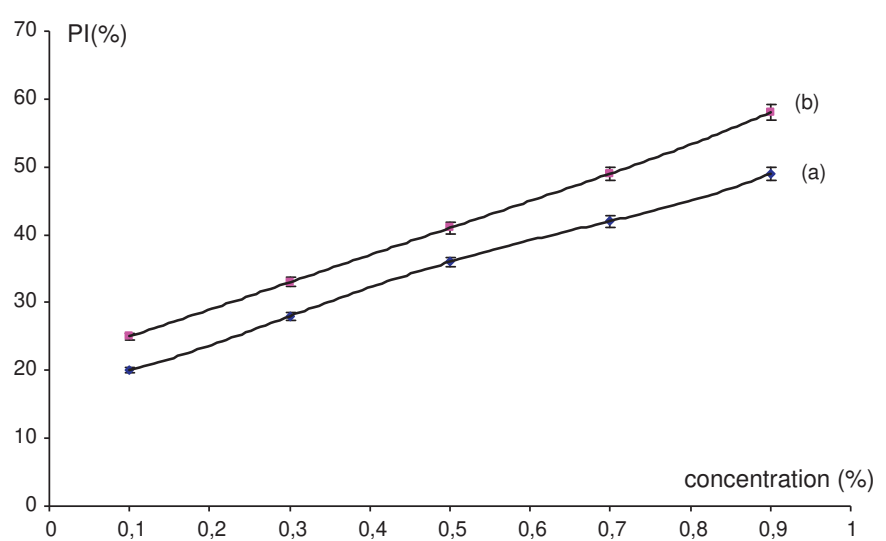

Fig. 6. Direct effect of procyanidins on arginase activity: (a) crude procyanidin extract and (b) procyanidin enriched extract. Mobile phase: $0.1 \mathrm{mM}$ Tris- $\mathrm{HCl}$ buffer $\mathrm{pH}=7.4,10 \mathrm{mM} \mathrm{MnCl}_{2}$. Flow rate: $0.4 \mathrm{~mL} / \mathrm{min}$. IMER temperature: $25^{\circ} \mathrm{C}$. Detection wavelength: $372 \mathrm{~nm}$. PI: percent inhibition.
Table 4

Effect of the concentration (\%) of the procyanidin enriched extract on $K_{\mathrm{m}}(\mathrm{mM})$ and $V_{\max }(\mu \mathrm{mol} / \mathrm{min})$ for arginase catalyzed NGB hydrolysis after $190 \mathrm{mM} \mathrm{NGB}$ injection. Mobile phase: $0.1 \mathrm{mM}$ Tris- $\mathrm{HCl}$ buffer $\mathrm{pH}=7.4,10 \mathrm{mM} \mathrm{MnCl}$. Flow-rate: $0.4 \mathrm{~mL} / \mathrm{min}$. IMER temperature: $25^{\circ} \mathrm{C}$. Detection wavelength: $372 \mathrm{~nm}$.

\begin{tabular}{lll}
\hline Concentration $(\%)$ & $K_{\mathrm{m}}(\mathrm{mM})$ & $V_{\max }(\mu \mathrm{mol} / \mathrm{min})$ \\
\hline 0.1 & $14.2(0.2)$ & $126.5(0.3)$ \\
0.3 & $14.3(0.2)$ & $119.7(0.2)$ \\
0.5 & $14.2(0.3)$ & $100.9(0.3)$ \\
0.7 & $14.5(0.2)$ & $95.8(0.2)$ \\
0.9 & $14.7(0.3)$ & $85.5(0.1)$ \\
\hline
\end{tabular}

Standard deviations were in parentheses.

Table 5

Effect of the concentration (\%) of the crude procyanidin extract on $K_{\mathrm{m}}(\mathrm{mM})$ and $V_{\max }(\mu \mathrm{mol} / \mathrm{min})$ for arginase catalyzed NGB hydrolysis after $190 \mathrm{mM}$ NGB injection. Mobile phase: $0.1 \mathrm{mM}$ Tris- $\mathrm{HCl}$ buffer $\mathrm{pH}=7.4,10 \mathrm{mM} \mathrm{MnCl}_{2}$. Flow-rate: $0.4 \mathrm{~mL} / \mathrm{min}$. IMER temperature: $25^{\circ} \mathrm{C}$. Detection wavelength: $372 \mathrm{~nm}$.

\begin{tabular}{lll}
\hline Concentration $(\%)$ & $K_{\mathrm{m}}(\mathrm{mM})$ & $V_{\max }(\mu \mathrm{mol} / \mathrm{min})$ \\
\hline 0.1 & $14.6(0.2)$ & $137.6(0.2)$ \\
0.3 & $14.7(0.3)$ & $126.5(0.2)$ \\
0.5 & $14.1(0.2)$ & $113.4(0.3)$ \\
0.7 & $13.9(0.4)$ & $100.1(0.2)$ \\
0.9 & $14.5(0.2)$ & $90.2(0.5)$ \\
\hline
\end{tabular}

Standard deviations were in parentheses.

manufacturer [22]) of procyanidin enriched (PE) extract. This high quantity of polymers can affect proximity and enzyme orientation. The enzyme active site without modification can normally interact easily with a substrate, whereas with the presence of long chain of polymer causing the change of an enzyme, as a result the $V_{\max }$ decreased. This result was confirmed by the fact that for the $\mathrm{CP}$ extract which contained a lower quantity of procyanidin polymer (decamer concentration $8.9 \mathrm{mg} / \mathrm{g}$ [22]), the decrease of the $V_{\max }$ values was lower than for the PE extract (Table 5). For the first time the direct effect of some plant-derived products on the arginase activity (and not only on their cellular action) and the modifications they induced on the enzyme were clearly visualized.

\section{Conclusion}

The proposed immobilization procedure was found appropriate to covalently bind arginase to a modified monolithic matrix (EDA CIM disk) maintaining enzyme activity. Moreover, the inclusion of arginase micro IMER in a chromatographic column allowed preserving the enzymatic activity from inactivating processes, widely increasing the stability of the enzyme with advantages in terms of accuracy and reproducibility. Considering the high cost of arginase and the difficulty of its isolation and purification the small amount of arginase immobilization on a reduced size monolithic CIM disk was found appropriate. As well, using this novel procedure, it was clearly visualized the direct role of some derived plant products to modulate the arginase activity. The effects of the pet ether extract from the stem bark of glomerata Roxob and procyanidin oligomers of cocoa decrease the arginase activity and confirmed the positive role of these compounds for treating NO-dependent smooth disorders

\section{Acknowledgments}

This work was supported by Grants 2008 from Direction Genérale de la Recherche from Programme National de Biotechnologie, Ministère de la Recherche, France. 


\section{References}

[1] G. Massolini, E. Calleri, A. Laveccia, F. Loiodice, D. Lubda, C. Temporini, G. Fracchiolla, P. Tortorella, E. Novellino, G. Caccialanza, Enantioselective hydrolysis of some 2-aryloxyalkanoic acid methyl esters and isosteric analogues using a penicillin G acylase based HPLC monolithic silica column, Anal. Chem. 75 (2003) 535-542.

[2] N. Markoglou, I.W. Wainer, On-line synthesis utilizing immobilized enzyme reactors based upon dopamine beta-hydroxylase, J. Chromatogr. B 766 (2002) $145-151$.

[3] M. Bartolini, V. Andrisano, I.W. Wainer, Development and characterization of an immobilized enzyme reactor based on glyceraldehyde-3-phosphate dehydrogenase for on-line enzymatic studies, J. Chromatogr. A 987 (2003) 331-340.

[4] V. Andrisano, M. Bartolini, R. Gotti, V. Cavrini, G. Felix, Determination of inhibitors' potency (IC50) by a direct HPLC method on an immobilized acethylcholinesterase column, J. Chromatogr. B 753 (2001) 375-383.

[5] A. Strancar, P. Koselj, H. Schwinn, D. Josic, Application of compact porous disks for fast separations of biopolymers and in-process control in biotechnology, Anal. Chem. 68 (1996) 3483-3488.

[6] S.M. Morris Jr., Regulation of enzymes of the urea cycle and arginine metabolism, Annu. Rev. Nutr. 22 (2002) 87-105.

[7] G. Wu, C.J. Meiniger, impaired arginine metabolism and NO synthesis in coronary endothelial cells of the spontaneously diabetic BB rat, Am. J. Physiol. 269 (1995) H1312-H1318.

[8] D. Bruch-Gerharz, O. Schnorr, C. Susschek, K.F. Beck, J. Pfeilschifter, T. Ruzicka, V. Kolbachofen, Arginase 1 over expression in psoriasis: limitation of inducible of nitric oxide synthase activity as a molecular mechanism for keratinocyte hyperproliferation, Am. J. Pathol. 162 (2003) 203-211.

[9] C. demougeot, A. Prigent Tessier, T. Bagnost, C. Andre, Y. Guillaume, M. Bouhaddi, A. Berthelot, Time course of vascular arginase expression and activity in spontaneously hypertensive rats, Life Sci. 80 (2007) 1128-1134.

[10] T. Bagnost, A. Berthelot, M. Boueddi, P. Laurant, C. André, Y. Guillaume, C. Demougeot, Treatment with the arginase inhibitor N[omega]-hydroxy-norL-arginine improves vascular function and lowers blood pressure in adult spontaneously hypertensive rat, J. Hypertens. 26 (2008) 1110-1118.

[11] T. Bagnost, Y.C. Guillaume, M. Thomassin, J.F. Robert, A. Berthelot, A. Xicluna, C. Andre, Immobilization of arginase and its application in an enzymatic chro- matographic column: thermodynamic studies of nor-NOHA arginase binding and role of the reactive histidine residue, J. Chromatogr. B: Analyt. Technol. Biomed. Life Sci. 856 (2007) 113-120.

[12] T. Bagnost, Y.C. Guillaume, M. Thomassin, A. Berthelot, C. Demougeot, C. Andre, Biochromatographic framework for analyzing magnesium chloride salt dependence on nor-NOHA binding to arginase enzyme, J. Chromatogr. B: Analyt. Technol. Biomed. Life Sci. 873 (2008) 37-40.

[13] R. Baggio, J.D. Cox, S.L. Harper, D.W. Speicher, D.W. Christianson, A new chromatographic assay for arginase activity, Anal. Biochem. 276 (1999) 251-253.

[14] G.M. Morris, R. Huey, W. Lindstrom, M.F. Sanner, R.K. Belew, D.S. Goodsell, A.J. Olson, AutoDock4 and AutoDockTools4: automated docking with receptive selector flexibility, J. Comput. Chem. 16 (2009) 2785-2791.

[15] M. Sanner, A. Olson, J. Spehner, Reduced surface: an efficient way to compute molecular surfaces, Biopolymers 38 (1996) 305-320.

[16] E. Cama, S. Pethe, J.-L. Boucher, S. Han, F.A. Emig, D.E. Ash, R.E. Viola, D. Mansuy, D.W. Christianson, Inhibitor coordination interactions in the binuclear manganese cluster of arginase, Biochemistry 43 (2004) 8987-8999.

[17] E.F. Pettersen, T.D. Goddard, C.C. Huang, G.S. Couch, D.M. Greenblatt, E.C. Meng T.E. Ferrin, UCSF chimera - a visualization system for exploratory research and analysis, J. Comput. Chem. 13 (2004) 1605-1612.

[18] N.J. Kuhn, S. Ward, M. Piponski, T.W. Young, Purification of human hepatic arginase and its manganese (II) - dependent and $\mathrm{pH}$ - dependent interconvertion between active and inactive forms: a possible $\mathrm{pH}$ - sensing function of the enzyme on the ornithine cycle, Arch. Biochem. Biophys. 320 (1995) 24-27.

[19] J. Custot, C. Moali, M. Brollo, J.L. Boucher, M. Delaforge, D. Mansuy, J.P. Tenu, J.L. Zimmermann, A new aminoacid $\mathrm{N} \omega$-hydroxy-nor-L-arginine: a highly affinity inhibitor of arginase well adapted to bind to its manganese cluster, J. Am. Chem. Soc. 119 (1997) 4086-4087.

[20] N.N. Raman, M. Khan, R. Hasan, Bioactive components from Ficus glomerata, Pure Appl. Chem. 66 (1994) 2287-2290.

[21] K.U. Schallreuter, S.M.A. Elwary, N.C.J. Gibbons, H. Rokos, J.M. Wood, Activation/deactivation of acethylcholinesterase by $\mathrm{H}_{2} \mathrm{O}_{2}$ : more evidence for oxidative stress in vitiligo, Biochem. Biophys. Res. Commun. 315 (2004) 502-508.

[22] S. Carnesecchi, Y. Schneider, S.A. Lazarus, D. Coehlo, F. Gosse, F. Raul, Flavanols and procyanidins of cocoa and chocolate inhibit growth and polyamine biosynthesis of human colonic cancer cell, Cancer Lett. 175 (2002) 147-155. 